\title{
Effect of Organization Culture on organization performance on Public Universities in Kenya
}

\author{
Gulali Donald Indiya \\ Dr. Johnmark Obura \\ Dr. J.K Mise \\ Maseno University, Kenya
}

Doi:10.19044/esj.2018.v14n19p15 URL:http://dx.doi.org/10.19044/esj.2018.v14n19p15

\begin{abstract}
Organizational culture is the adhesive holding companies together in a country and is characterized by stability processes, collectivity and predictability, and is a source of recreation, of new opportunities as well as of conflicts and of dynamics. Recent studies on organization culture have anchored organization culture on individualism, uncertainty avoidance power distance, masculinity and long term orientation, employee longevity, adhocracy culture and clan culture. This contradictions reveal that it remains unknown of organization culture based on individual values, assumptions, values and artifacts influence organization performance. This study seeked to establish the effects of organization culture on organization performance in public universities in Kenya. Guided by Contingency Theory of organization structure, a correlation research design and a population of 215 management personal were used from 11 public universities in Kenya certified by Kenya Bureau of Standards. The study adopted a census survey with response at 94.4 $\%$. Primary data was collected using questionnaires. Using Pearson Product Moment Correlation the study indicates that there was a strong positive significant correlation between organizational culture and organizational performance $(\mathrm{r}=.804, \mathrm{p}<.05)$. Regression analyses revealed that organizational values had the strongest unique contribution to the organizational performance $(\beta=.394, p=.000)$, followed by organizational artifacts $(\beta=.347, p=.000)$ and finally individual believes $(\beta=.155, p=.001)$. The overall form of organizational culture had a unique significant contribution on organizational performance $(\beta=.804, p=.000)$, and accounted for $64.6 \%$ variance in organizational performance. The study recommends that universities should work on ensuring that there are positive believes that can enhance organizational performance through improving and maintaining quality management systems basing on the existing culture.
\end{abstract}


Keywords: Culture, performance, Quality Management System

\subsection{Introduction:}

Increasing globalization requires more interaction among individuals from a diverse culture perspective. Maximization and capitalization of diversity in a work environment has become an important issue for management in the developing countries. According to Deal and Peterson (2009), the culture of any organization is a significant factor in its success or failure. Deal and Peterson (2009), defines organization culture as a pattern of basic assumptions invented, discovered, or developed by a given group as it learns to cope with its problems of external adoption and internal integration that has worked well enough to be considered valid to an organization. From the literature, the relationship between organization culture, quality management system and organization performance has not been the subject of much attention among higher education institutions in Kenya. Some important areas are under explored in the relationship between organization culture and organization performance, while others on the quality management system adoption and organization performance. For example the subject has been primarily investigated in the context developed countries while inadequate attention has been given to developing countries.

In the development of any nation, education plays a critical role that leads to the overall development of a country's economy (Ali et al., 2010) and cannot be underestimated. The global demand in education has led to the development of both private and public owned (Mathooko, 2013). As global competition intensifies due to changes in the industry structure and the emergence of new technologies, organizations seek to employ skilled and competent personal. Higher education has stepped in to create and sustain a country's public developments, through creation of Universities, technical institutions and colleges (Chang'ach 2014).

Organizational culture is the adhesive holding companies together in a country, is characterized by stability processes, collectivity and predictability, and is a source of recreation, of new opportunities as well as of conflicts and of dynamics. Recent studies on organization culture Aluko, (2003), Allard (2010) and Fakhar, Iqbal and Gulzar (2013), translate organization culture with respect to culture on employee participation, openness to communication, risk taking and innovation, customer service orientation and reward system as its attributes; Wahjudi.et.al (2016) study anchored organization culture on individualism, uncertainty avoidance power distance, masculinity and long term orientation; Allard (2010), employee longevity; Naranjo et. al, (2016) adhocracy culture and clan culture. This contradictions reveal that it remains unknown of organization culture based on individual values, assumptions, values and artifacts influence organization performance. Moreover, studies by 
Tsai (2011); ul Mujeeb and Ahmad (2011); Aluko (2003); Gulzar (2013); Allard (2010); Fakhar, Iqbal and Gulzar, (201)3; Naranjo et. al, (2016); Agwu, 2014 and Further Zhu. et al 2016) found a positive relation on organization culture and organization performance. while in other studies, the impact was positive but weak (Acar and Acar, 2012; Allard, 2010 and Mohammad, 2006) yet another set of studies has found that no relationship exists ( Nikpour, 2017; Allard, 2010; Lapiņa, Kairiša, and Aramina, 2015 and Wahjudi.et.al 2016) methodological reasons may account for these contradictions.

In the developing countries, organization culture is often unnoticed, yet it is the cornerstone to execute the strategy to reach the goal of the organizations in significant manner. Liker and Hoseus (2008) states that it is not necessary for people to think in exactly the same way, but it is important that there be shared core values and that everyone agrees about how to carry out work. Aluko, (2003), ul Mujeeb and Ahmad. (2011), Gulzar (2013), Wahjudi et al. (2016), Tsai. (2011) Taiwan Naranjo et al., (2016) studies on organization culture were carried out on health and manufacturing organizations in Nigeria, Thailand and Indonesia. There is no known information about the effects of organization culture on Higher education institutions. Therefore, this study seeks to establish the effects of organization culture on organization performance in public universities in Kenya.

\subsection{Organization Culture and Organization Performance}

Aluko, (2003) in a study on impact of culture on organizational performance in selected textile firms in Nigeria, attempted to determine the nature of the relationship, the determinants of performance and the ways in which culture interacts with other factors within an organization. Using both qualitative and quantitative methodologies with a study population of 630 , the study found out that irrespective of organization employees cultural backgrounds, organization employees appeared to have imbibed the industrial way of life. The study further indicated a strong association between the cultural variables and level of commitment, staff attrition, and positive attitude towards work. However, culture did not translate directly to high levels of organization performance since other variables were at work such as economy, technology and political climate.

ul Mujeeb and Ahmad. (2011), in their study on the impact of Organizational Culture on Performance Management Practices in Pakistan found out a positive relationship between elements of organization culture and performance management at a confidence level of 0.99. This study adopted exploratory research design, on a population of 60 COMSATS institute of information technology in Pakistan. In addition, from the correlation analysis of organization culture traits, management practice revealed a positive 
significance with involvement 0.736 , consistency 0.837 , adaptability 0.767 and mission $0.815(\mathrm{r}>0.01)$

Nikpour, (2017) based his research on the mediating role of employee's organizational commitment on organizational culture and organizational performance, used a survey study design on 190 employees in education office of Kerman province. The study focused on involvement, consistence, adaptability and mission as organization culture attributes and efficiency, effectiveness, productivity, quality and innovation as organization performance attributes. He found out that organization culture had a positive impact on employee organization commitment and organization performance. The study analysis pointed that organization culture beyond its direct impact on organization performance indirectly influence organization performance through employees organization commitment. Moreover, the indirect impact had a correlation value of 0.7 higher than the direct impact of 0.68 hence organization commitment had a mediator impact on the relationship between organization culture and organization performance.

A quantitative survey based on non-experimental research by Allard (2010), indicated a significant negative relationship between employee, organization culture and organization performance with $r=-0.52 \mathrm{p}<0.001$. Further, the study revealed that employee longevity with an organization, moderated the relationship between employee organization culture and organization performance with $p=-15$ and $p=0.12$. Fakhar, Iqbal and Gulzar (2013) also adopted a survey method to determine the impact of organizational culture on employees' job performance in Software Houses in Pakistan, on a sample of 110 employees. The study adopted descriptive statistics, correlation and regression analysis. The study concluded that organization culture has a significant positive impact on employee job performance with an adjusted $\mathrm{R}^{2}$ of 0.716. Pearson correlation between organization culture and employee performance was 0.415 which is a positive value and having a moderate effect because the value is between 0.3 to 0.7. Allard (2010) and Fakhar, Iqbal and Gulzar (2013) study based organization culture on employee participation, openness to communication, risk taking and innovation, customer service orientation and reward system as its attributes.

In an empirical study carried out in Indonesia to explain the relationship between organizational culture and firm performance. Wahjudi.et.al (2016) postulated that organization culture only explains $20 \%$ of a firm's performance while other factors such as total quality management, total productive maintenance, supply chain, management practice business strategy and public policy. Moreover, from the $20 \%$ only individualism and uncertainty avoidance significantly impact firm's performance unlike power distance, masculinity and long term orientation in Indonesian manufacturing firms. Shi, Veenstra \& Lee-Chin. (2017) also conducted a study on the 
moderating effect of cultural values on the relationship between corporate social performance and corporate financial performance. The study data set covered 3,574 firms from 37 different countries. This study revealed that the interactions between corporal social performance and individualism, power distance, masculinity and indulgence have a negative effect on corporal financial performance while the interaction between corporal social performance and long-term orientation has a positive effect on corporal financial performance. This study finding highlights the importance of cultural values in influencing the valuation of an organization.

Using a cross sectional survey method, Tsai, (2011) analyzed 300 hospital nurses in Taiwan and found out that organization culture was significant positive correlated with leadership behavior and job satisfaction with $r=0.55$ and $r=0.47$ respectively. Allard, (2010) also used a cross sectional survey method from 250 organizations in examining the relationship between organizational culture and performance. From his study organization culture was an independent variable with innovation, leadership, decision making and communication as its attributes. The study revealed that organization culture and employee performance, were positively related but weak with a correlation coefficient of 0.245 at a significant level 0.05 (1-tailed test)

In a survey study conducted by Acar and Acar (2012) on the effects of organizational culture and innovativeness on business performance in healthcare industry, a survey design on 332 employees of 65 private hospitals revealed a positive effect of innovation and organization culture on business performance. Mohammad. (2006) also carried out a survey study on elicit responses from hospital managers and employees and found out that the success of TQM in hospitals with organic organizational structure and medium organizational culture was higher than mechanistic and bureaucratic hospitals with weak organizational culture. Further Zhu. et al (2016) conducted a survey126 juvenile product sector firms and revealed that the underlying assumption of organization safety first affects the espoused values and artifacts of organizational culture

Agwu (2014) investigated organizational Culture and Employees Performance in the National Agency for Food and Drugs Administration and Control, Nigeria. From this study organization culture was based on shared values, believes and norms. A descriptive research design was adopted on 420 employees. The study revealed that there is a strong significant relationship between organization culture and increased employee productivity.

Lapiņa, Kairiša, \& Aramina. (2015) carried out a study on the role of organizational culture in the quality management of university. This study was based on scientific publications review using logical and comparative analysis method. Interestingly, the findings of the study revealed that organizational 
culture makes ground for quality management and is directly connected to development. Further, Naranjo et. al, (2016) carried out a study on links between organizational culture, innovation, and performance in Spanish companies, and was based on more than fifteen employees located in southeast Spain. The empirical findings of the study revealed that the organization culture affects performance and firms' innovation basing on adhocracy culture and clan culture.

Studies by Aluko,(2003), and Shi, Veenstra \& Lee-Chin. (2017) revealed a negative significance moreover, Allard, I. N. (2010) study revealed a positive significance though a weak one on the interaction between organization culture on performance. Further, studies survey studies by ul Mujeeb and Ahmad. (2011), Nikpour (2017), Allard (2010), Tsai (2011), Acar and Acar (2012) and Mohammad. (2006) revealed a positive significance on organization culture and employee performance, corporate financial performance and corporal social performance respectively. From the above studies, there is a clear finding that organization culture has both a positive or negative impact on performance; however, these studies were carried out service institutions such as hospital ICT institution and national funds agencies in Nigeria, Pakistan and Indonesia public and private institutions. The current study will be based on Kenyan public Universities.

From their studies, Nikpour (2017), Allard (2010) and Wahjudi.et.al (2016) focused on organization culture basing on different aspects in that; Nikpour (2017), based his study on involvement, consistence, adaptability and mission as organization culture attributes, Allard (2010) focused on employee participation, openness to communication, risk taking and innovation, customer service orientation and reward system as its attributes while Wahjudi.et.al (2016) focused on individualism, uncertainty avoidance power distance, masculinity and long term orientation. Moreover, Agwu (2014) on his study shared values believes and norms were used as organization culture attributes, which will be in line with the current study though it only focused on three cultural attributes while the current study will adopt artifacts as its fourth attribute.

\subsection{Methodology}

The study will adopt a correlation design. Correlation research design aims to ascertain if there are significant associations between study variables (Kothari, 2004), on 11 public universities in Kenya who attained QMS certification through KEBS. A target population is that group of people from whom the study is designed and generalizations of the findings are made from (Kothari, 2004). The study unit of analysis will entail organization management personal in the 11public universities. This will not include the 
other subsidiaries either operating under the principal University umbrella or name.

A census survey approach was adopted and a sample frame obtained from the 215 management Personnel based on 11 vice chancellors, 38 deputy vice chancellors, 11 finance officers, 25 registrars, 106 deans and 11 librarians. Primary data was collected using questionnaires from senior and top managers. Questionnaires were much preferred by the study since it can be used to gather data in a short span of time and within minimum expense. (Meller, 2001) Unlike interviews, Questionnaires can be administered to a large number of respondents at different geographic location in a short time period yet guarantees high response rate with a diversity of information on the same (Grinnell, 2001).

Data collected was analyzed quantitatively using descriptive statistics such as means, frequency counts and percentages to compare variables numerically and ascertain a pattern in the data set. Further inferential statistics, Chi-square test at $95 \%$ confidence interval will be used to compare the difference between categories frequencies when data is categorical and drawn from a population with a homogenous distribution (Oso and Onen, 2009). To achieve the study objectives the study will measure the degree of association.

The study adopted multiple regression model to determine the relationship between the variables of the study (adopted from Aiken and West, 1991); such that:

\section{Where:}

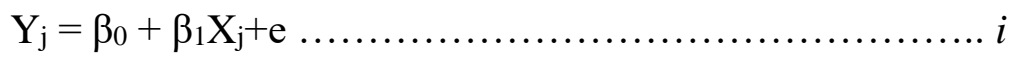

$\beta_{0} \quad$ coefficient of the predictors

$\beta_{1} \quad$ regression coefficient to be estimated

$\mathrm{Y}_{\mathrm{j}}$ coefficient of a single organization performance indicator (Organization efficiency, Organization effectiveness)

X theoretically defined independent variables (Quality policy, Process planning,continual improvement, Investment in material and human resource, streamlining process)

$e \quad$ error term/ residual factor not explained by the $\mathrm{X}$ variables analyzed.

\subsection{Findings}

The main objective of the study was to determine the effect of organizational culture on organizational performance of public universities. Te first step towards achieving this objective was to measure the organizational culture and later on determine its effect on organizational performance. Organizational culture was categorized into four categories. This include the organizational values, artifacts, individual belies and assumptions. The first variable was the organizational values. All the constructs under organizational culture measured on a five point likert scale of $1-5$, where $1=$ 
Not at all, $2=$ little extent, $3=$ Moderate extent, $4=$ To a large extent and $5=$ A very large extent. Frequency counts, percentages, means and standard deviations were the main tools of analysis on the measurement of this construct. The findings are presented as shown in Table 4.18.

\subsection{Organization Culture}

Table 4.1 Values

\begin{tabular}{|c|c|c|c|c|c|c|c|}
\hline Values & $\begin{array}{c}\text { NAL(1) } \\
\text { f(\%) }\end{array}$ & $\begin{array}{l}\text { LE(2) } \\
f(\%)\end{array}$ & $\begin{array}{c}\text { ME(3) } \\
\text { f(\%) }\end{array}$ & $\begin{array}{c}\mathbf{L E}(4) \\
\mathbf{f}(\%)\end{array}$ & $\begin{array}{l}\operatorname{VLE}(5) \\
f(\%)\end{array}$ & $\mathbf{M}$ & STD \\
\hline $\begin{array}{l}\text { The vision, mission } \\
\text { and values of this } \\
\text { University are very } \\
\text { clear, focused and } \\
\text { easily conceptualized }\end{array}$ & $9(5.5)$ & $0(0.0)$ & $24(14.5)$ & $61(37.0)$ & $71(43.0)$ & 4.13 & 1.00 \\
\hline $\begin{array}{l}\text { All employees adhere } \\
\text { strictly to the } \\
\text { organization policies } \\
\text { and procedures }\end{array}$ & $0(0.0)$ & $16(9.7)$ & $50(30.3)$ & $55(33.3)$ & $44(26.7)$ & 3.77 & .95 \\
\hline $\begin{array}{l}\text { The adherence to } \\
\text { policies have reduced } \\
\text { cases of uncounted } \\
\text { for water, service } \\
\text { hours and revenue } \\
\text { collection efficiency }\end{array}$ & $4(2.4)$ & $8(4.8)$ & $46(27.9)$ & $86(52.1)$ & $21(12.7)$ & 3.67 & .85 \\
\hline $\begin{array}{l}\text { Our institution "es } \\
\text { service charter is } \\
\text { clearly written and } \\
\text { focused on improving } \\
\text { service delivery }\end{array}$ & $0(0.0)$ & $13(7.9)$ & $36(21.8)$ & $51(30.9)$ & $65(39.4)$ & 4.02 & .95 \\
\hline $\begin{array}{l}\text { The staff at the front } \\
\text { office record contacts } \\
\text { of customers and kept } \\
\text { well for ease of } \\
\text { accessibility }\end{array}$ & $4(2.4)$ & $12(7.3)$ & $57(34.5)$ & $67(40.6)$ & $25(15.2)$ & 3.57 & .91 \\
\hline $\begin{array}{c}\text { Managers are } \\
\text { consistent and fair in } \\
\text { administering work } \\
\text { policies }\end{array}$ & $8(4.8)$ & $28(17.0)$ & $34(20.6)$ & $70(42.4)$ & $25(15.2)$ & 3.44 & 1.09 \\
\hline
\end{tabular}

KEY: NAA-Not at All, LE-Large Extent, ME-Moderate Extent, VLE-Very Large Extent, M-Mean, SD-Standard Deviation.

The findings in table 4.1 indicate the extent of the organization's culture rating by the respondents. The university has very clear, focused and easily conceptualized vision, mission and values. This is well illustrated as supported by the majority of the respondents $71(43.0 \%)$ who reported to a very large extent and $61(37.0 \%)$ who reported to a large extent. The mode of the findings was 5, rating very large extent whereas the mean was 4.13 with a 
standard deviation of 1.00. This gives a clear implication to a very large extent that the organization has a very clear, focused and easily conceptualized vision, mission and values though with notable variations in the responses shown by a standard deviation of 1.00. Supporting this is the employees adherence to the organization's policies and procedures with the majority $55(33.3 \%)$ reporting a large extent and 44(26.7) reporting a very large extent. The mode of the findings was 4 which rated very large extent with a mean of 3.77 and standard deviation of 0.95 . This indicates clearly that employees adhere strictly to the organization's policies and procedures.

In addition to that it is clear from the majority $86(52.1 \%)$ who indicated to a large extent and 46(27.9\%) to a moderate extent and being supported to a very large extent by only $21(12.7 \%$ ) that the adherence to policies has reduced cases of uncounted for water, service hours and efficiency in revenue collection. Having a mean of 3.67 and a standard deviation of 0.85 supports the finding. The findings also indicate that to a very large extent with $65(39.4 \%)$ stakeholders and to a large extent with 51(30.9) stakeholders as well as to a moderate extent with $36(21.8 \%)$ stakeholders that the institution has a clearly written charter that focuses on improving service delivery. This is supported by a mean of 4.02 with a standard deviation of 0.95 .

In terms of record keeping of customers contacts for easy accessibility by the front office staff, majority of the respondents $67(40.6 \%)$ support to a large extent with $57(34.5 \%)$ of the respondents supporting to a moderate extent and $25(15.2 \%)$ of the respondents supporting to a very large extent that the staff at the front office records and keeps the contacts of customers very well for easy accessibility. This is supported by a mean of 3.57 and a standard deviation 0.91. Lastly, the findings also indicate to a large extent with $70(42.4 \%)$ respondents and to a moderate extent with $34(20.6 \%)$ of the respondents supporting that managers are consistent and fair in administering work policies. In addition to that $28(17.0 \%)$ of the respondents support to a little extent with $25(15.2 \%)$ of the respondents supporting to a very large extent the same idea that managers are consistent and fair in administering work policies. This idea is evenly rated as indicated by a mean of 3.44 with notable variations in the responses shown by a standard deviation of 1.09 , slightly above 1.00 .

In summary, the most widely practiced value in the organization's culture is the clarity, focus and ease in conceptualization of the vision, mission and values with the highest mean of 4.13and a standard deviation of 1.00. The least value practiced in the organization's culture as well as the evenly rated value is the managers' consistency and fairness in administering work policies. It has the least mean of 3.44 with a standard deviation of 1.09 that shows notable variations in the responses. In general, the organization has a well-organized structure in terms of its cultural values 


\section{2 organizational artifacts}

Another task in achieving the objectives of the study was to rate the views of respondents in the organization concerning an independent variable, i.e. organizational artifacts. This was done on a five scale rating using subscales to identify how the artifacts, being subset of the organization's culture contribute to the structure and hence performance of the organization. The respondents were asked to give their views concerning how they perceived certain statements about their organization. The rates of 1-5 scale was used where $1=$ Not at all, $2=$ little extent, $3=$ moderate extent, $4=$ to a large extent and $5=$ to a very large extent. The findings were then analyzed using descriptive statistics mainly means and standard deviations. Tables 4.2 below present the various findings about artifacts.

Table 4.2 Organizational Culture; Artifacts

\begin{tabular}{|c|c|c|c|c|c|c|c|}
\hline Artifacts & $\begin{array}{l}\text { NAL(1) } \\
\text { f(\%) }\end{array}$ & $\begin{array}{l}\mathbf{L E}(2) \\
\mathbf{f}(\%)\end{array}$ & $\begin{array}{c}\operatorname{ME}(3) \\
\mathbf{f}(\%)\end{array}$ & $\begin{array}{c}\text { LE(4) } \\
\mathbf{f}(\%)\end{array}$ & $\begin{array}{l}\text { VLE(5) } \\
\text { f(\%) }\end{array}$ & $\mathbf{M}$ & STD \\
\hline $\begin{array}{l}\text { Employees put on } \\
\text { identification badge } \\
\text { always at work }\end{array}$ & $4(2.4)$ & $32(19.4)$ & $32(19.4)$ & $68(41.2)$ & $29(17.6)$ & 3.50 & 1.06 \\
\hline $\begin{array}{l}\text { Employees are rewarded } \\
\text { for their good performance }\end{array}$ & $33(20.0)$ & $41(24.8)$ & $41(24.8)$ & $38(23.0)$ & $12(7.3)$ & 2.73 & 1.22 \\
\hline $\begin{array}{l}\text { Our Organization } \\
\text { embraces modern } \\
\text { technology in } \\
\text { communicating with } \\
\text { clients e.g. sending } \\
\text { students results and fees } \\
\text { status via email or sms }\end{array}$ & $20(12.1)$ & $4(2.4)$ & $75(45.5)$ & $46(27.9)$ & $20(12.1)$ & 3.25 & 1.10 \\
\hline $\begin{array}{l}\text { Embracing Modern } \\
\text { technology by our } \\
\text { organization has improved } \\
\text { our revenue collection } \\
\text { through school fees }\end{array}$ & $20(12.1)$ & $8(4.8)$ & $45(27.3)$ & $80(48.5)$ & $12(7.3)$ & 3.33 & 1.10 \\
\hline $\begin{array}{l}\text { Our organization prepares } \\
\text { and gives free publications } \\
\text { to clients on the } \\
\text { University's achievements } \\
\text { every year }\end{array}$ & $25(15.2)$ & $12(7.3)$ & $50(30.3)$ & $54(32.7)$ & $24(14.5)$ & 3.25 & 1.23 \\
\hline $\begin{array}{l}\text { The publications of } \\
\text { company achievements } \\
\text { lead to better performance } \\
\text { by our company }\end{array}$ & $12(7.3)$ & $12(7.3)$ & $62(37.6)$ & $50(30.3)$ & $29(17.6)$ & 3.43 & 1.09 \\
\hline $\begin{array}{c}\text { Visitors to our } \\
\text { organization are treated } \\
\text { well }\end{array}$ & $13(7.9)$ & $0(0.0)$ & $53(32.1)$ & $75(45.5)$ & $24(14.5)$ & 3.60 & .99 \\
\hline
\end{tabular}

KEY: NAA-Not at All, LE-Large Extent, ME-Moderate Extent, VLE-Very Large Extent, M-Mean, SD-Standard Deviation.

Source: Spss data 2017 
From the findings in table 4.2, there is clear evidence that the employees in the organization always put on identification budges. This is supported to a large extent by $68(41.2 \%)$ and to a very large extent by $29(17.6 \%)$ of the respondents. A mean of 3.50 also supports the idea that the employees always put on identification budges at work though with varied opinions, views and responses shown by a standard deviation of 1.06 which is slightly above 1.00. However, there are different opinions concerning rewarding employees who perform well. This is supported by 41(24.8\%) of the respondents to a little extent and moderate extent. This is also supported by $38(23.0 \%)$ of the respondents to large extent. These findings are supported by a mean of 2.73 which clearly indicate that to a moderate extent ,the employees put on identification budges while at work, however with notable variations in the responses indicated by the standard deviation of 1.22 that is slightly above 1.00 .

Furthermore, there is a clear evidence that the organization embraces modern technology in communicating with clients e.g. sending student results and fee status via email or sms as can be seen by the findings from $75(45.5 \%)$ of the respondents supporting the idea to a moderate extent and 46(27.9\%) of the respondents supporting the idea to a large extent. A mean of 3.25 clearly support the idea that the organization embraces modern technology in communicating with clients, however with notable variations as indicated by a standard deviation of 1.10 . These variations are also clear as seen by tie in the number and percentage of respondents $25(12.3 \%$ ) who support the idea to a very large extent and those who say Not at all. Having embraced modern technology in the organization has improved revenue collection through school fees. This is so clear as it is supported by $80(48.5 \%)$ of the respondents to a large extent and $45(27.3 \%)$ of the respondents to a moderate extent. The mean of 3.33 with a standard deviation of 1.10 supports the idea.

In addition to that, it is clear from the majority $54(32.7 \%)$ of the respondents who to a large extent and 50(30.3\%) of the respondents who to a moderate extent that the organization prepares and gives free publications to clients on the university achievements every year. The mean of 3.25 supports the statement, however there are varied opinions indicated by a standard deviation of 1.23. The findings also indicate that the publications of the company achievements lead to better performance by the company. This is evident from the findings of 62(37.6\%) respondents who support the idea to a moderate extent and 50(30.3\%) of the respondents who support the idea to large extent. This is supported by a mean 3.43 with a standard deviation of 1.09 that indicates notable variations in the responses as it is slightly above 1.00

Lastly, in relation to the kind of treatment given to the visitor, and organization, majority of the respondents $75(45.5 \%)$ support to a large extent 
while 53(32.1\%) of the respondents support to a moderate extent that visitors to the organization are treated well. A mean of 3.60 with a standard deviation of 0.99 support the idea that visitors are treated well at the organization.

In summary, the most considered artifact in the organization's culture is the reception and treatment of visitors at the organization, having a mean of 3.60 with a standard deviation of 0.99 showing little or unnoticed variations in the respondents' responses. However, the least considered artifact in the organization's culture is rewarding of employees based on their performance, with a mean of 2.73 with a standard deviation of 1.22 showing notable variations in the responses. However, generally, the organization has a wellorganized structure in terms of its cultural artifacts.

\subsection{Individual believes}

The second last subscale considered under organizational culture was the individual believes. The study sought respondents views on individual believe, which entailed empowerment aids, respect, innovation and team work. The study adopted a five point likert scale of 1-5 scale was used where $1=$ Not at all, $2=$ little extent, $3=$ moderate extent, $4=$ to a large extent and $5=$ to a very large extent. The results are presented as shown in Table xx using frequency counts, percentages, means and standard deviations. The higher the mean, i.e, a mean of 2.5 and above the more the organizations practice these values, likewise, the lower the mean, the less perceptive these values emerge.

\section{Table 4.3 Individual Believes}

\begin{tabular}{|c|c|c|c|c|c|c|c|}
\hline Individual Believes & $\begin{array}{l}\text { NAL(1) } \\
\text { f(\%) }\end{array}$ & $\begin{array}{l}\text { LE(2) } \\
\text { f(\%) }\end{array}$ & $\begin{array}{l}\text { ME(3) } \\
\mathbf{f}(\%)\end{array}$ & $\begin{array}{c}\text { LE(4) } \\
\text { f(\%) }\end{array}$ & $\begin{array}{c}\text { VLE(5) } \\
\text { f(\%) }\end{array}$ & $\mathbf{M}$ & STD \\
\hline $\begin{array}{l}\text { Empowerment aids in } \\
\text { training and discovering } \\
\text { potential future leaders. }\end{array}$ & $13(7.9)$ & $4(2.4)$ & $59(35.8)$ & $65(39.4)$ & $24(14.5)$ & 3.52 & 1.02 \\
\hline $\begin{array}{l}\text { All employees should } \\
\text { share the same stand in } \\
\text { decision making process. }\end{array}$ & $13(7.9)$ & $12(7.3)$ & $46(27.9)$ & $58(35.2)$ & $36(21.8)$ & 3.57 & 1.13 \\
\hline $\begin{array}{l}\text { Employees respect each } \\
\text { other's needs when } \\
\text { making decisions in the } \\
\text { university. }\end{array}$ & $13(7.9)$ & $0(0.0)$ & $83(50.3)$ & $53(32.1)$ & $16(9.7)$ & 3.37 & .93 \\
\hline $\begin{array}{l}\text { Innovation creates both } \\
\text { risks and opportunity for } \\
\text { the university. }\end{array}$ & $13(7.9)$ & $8(4.8)$ & $51(30.9)$ & $61(37.0)$ & $32(19.4)$ & 3.57 & 1.08 \\
\hline $\begin{array}{l}\text { Employees value team } \\
\text { work to individualism. }\end{array}$ & $17(10.3)$ & $12(7.3)$ & $42(25.5)$ & $57(34.5)$ & $37(22.4)$ & 3.53 & 1.20 \\
\hline
\end{tabular}

KEY: NAA-Not at All, LE-Large Extent, ME-Moderate Extent, VLE-Very Large Extent, M-Mean, SD-Standard Deviation.

Source: Spss data 2017 
The findings in Table 4.3 indicates that highly practiced individual believes in the public universities were sharing of the same standards in decision making by employees $(\mathrm{M}=3.57, \mathrm{SD}=1.13)$ and innovation to create both risks and opportunity for the university $(\mathrm{M}=3.57, \mathrm{SD}=1.08)$. Concerning the sharing of the same standard of decision making by employees, the findings by majority, 58(35.2\%) of the respondents revealed that it was practiced to a large extent. Majority, 61(37.0\%) of the respondents also indicated that innovation to create both risks and opportunities for the university was practiced to a large extent. The findings also indicates that the extent to which employees valued team work to individualism was large extent $(\mathrm{M}=3.53, \mathrm{SD}=1.20)$ with majority, $57(34.5 \%)$ of the respondents indicating that it was to a large extent. Empowerment aids in training and discovering potential future leaders also emerged to be high $(\mathrm{M}=3.52, \mathrm{SD}=1.02)$, with majority $57(34.5 \%)$ indicating a large extent. Finally, the findings revealed that employees' respect to each other's needs when making decisions in the university was moderately practiced $(\mathrm{M}=3.37, \mathrm{SD}=.93)$, also supported by majority of the respondents, $83(50.3 \%)$ who indicated a moderate extend.

\subsection{Organizational assumptions}

The final subscale under organizational culture considered was the organizational assumptions. The study also sought to measure the respondents views on the extent to which the organization practiced its belies based on the employee assumptions. The constructs theoretically aligned to organizational assumptions were, reward of individual performance by the universities, reward of team performance, acknowledgement of individual employee credentials and strength, chance to express self and punctuality at meetings. The constructs were measured on a five point likert scale of 1-5 scale was used where $1=$ Not at all, $2=$ little extent, $3=$ moderate extent, $4=$ to a large extent and $5=$ to a very large extent. The findings are presented using frequency counts, percentages, means and standard deviations as shown in Table 4.4 that follows. 
Table 4.4 Assumptions

\begin{tabular}{|c|c|c|c|c|c|c|c|}
\hline Assumptions & $\begin{array}{c}\text { NAL(1) } \\
\mathbf{f}(\%)\end{array}$ & $\begin{array}{l}\mathbf{L E}(2) \\
\mathbf{f}(\%)\end{array}$ & $\begin{array}{c}\mathrm{ME}(3) \\
\mathbf{f}(\%)\end{array}$ & $\begin{array}{c}\mathbf{L E}(4) \\
\mathbf{f}(\%)\end{array}$ & $\begin{array}{c}\text { VLE(5) } \\
f(\%)\end{array}$ & $\mathbf{M}$ & STD \\
\hline $\begin{array}{l}\text { The University } \\
\text { rewards } \\
\text { individual } \\
\text { performance. }\end{array}$ & $17(10.3)$ & $21(12.7)$ & $49(29.7)$ & $66(40.0)$ & $12(7.3)$ & 3.22 & 1.08 \\
\hline $\begin{array}{l}\text { The University } \\
\text { rewards team } \\
\text { performance. }\end{array}$ & $17(10.3)$ & $25(15.2)$ & $45(27.3)$ & $62(37.6)$ & $16(9.7)$ & 3.22 & 1.12 \\
\hline $\begin{array}{l}\text { The University } \\
\text { acknowledges } \\
\text { individual } \\
\text { employees } \\
\text { credentials and } \\
\text { strengths. }\end{array}$ & $9(5.5)$ & $28(17.0)$ & $29(17.6)$ & $71(43.0)$ & $28(17.0)$ & 3.50 & 1.11 \\
\hline $\begin{array}{l}\text { I am not given } \\
\text { a chance to air } \\
\text { my feelings. }\end{array}$ & $16(9.7)$ & $44(26.7)$ & $56(33.9)$ & $24(14.5)$ & $25(15.2)$ & 2.97 & 1.18 \\
\hline $\begin{array}{l}\text { I am required } \\
\text { to be punctual } \\
\text { in all meetings }\end{array}$ & $8(4.8)$ & $8(4.8)$ & $29(17.6)$ & $62(37.6)$ & $58(35.2)$ & 3.92 & 1.08 \\
\hline
\end{tabular}

KEY: NAA-Not at All, LE-Large Extent, ME-Moderate Extent, VLE-Very Large Extent, M-Mean, SD-Standard Deviation

Source: Spss data 2017

From the findings in Table 4.4, it emerged that the most sought after organizational culture trait under assumption was punctuality at meetings which was high, $(\mathrm{M}=3.92, \mathrm{SD}=1.08)$, with majority, $62(37.6 \%)$ of the respondents indicating that it was practiced to a large extent and 58(35.2\%) indicating that it was to a very large extent. Acknowledgement of the individual employees credentials and strength by the universities emerged to be the second highest $(\mathrm{M}=3.50, \mathrm{SD}=1.11)$ with majority, $71(43.0 \%)$ of the respondents indicating that it was practiced to a large extent. The findings also revealed that the levels of reward to individual and team performance by the universities were moderate $(\mathrm{M}=3.22, \mathrm{SD}=1.08)$ and $(\mathrm{M}=3.22, \mathrm{SD}=1.12)$ respectively. However, majority of the respondents, 66(40.0\%) response on reward on individual performance indicated that it was to a large extent and supported by $12(7.3 \%)$ indicating a very large extent. For the reward of team performance, majority, 62(37.6\%) indicated large extent while 16(9.6\%) indicated a very large extent.

The second towards achieving the objective of the study was coming up with the summary statistics on the four variables of the organizational structure. The means were meant to later on correlate with organizational performance in order to establish some associations. The summary statistics on 
organizational culture are presented in Table 4.5 for comparison with those of organizational performance.

Table 4.5 Summary Statistics on Organizational Culture

\begin{tabular}{ccc}
\hline Organizational Culture & M & SD \\
\hline Organization Culture Values & 3.77 & .63 \\
Organization Culture Artifacts & 3.30 & .83 \\
Organization Culture Individual Belief & 3.51 & .90 \\
Organization Culture Assumptions & 3.37 & .79 \\
Overall Mean Organizational Culture & 3.49 & .63 \\
\hline
\end{tabular}

Source: Spss data 2017

The findings in Table 4.5 indicates that the overall mean for the organizational culture was highly rated $(\mathrm{M}=3.77, \mathrm{SD}=.63)$ as compared to the other variables. Individual believes emerged the second, $(\mathrm{M}=3.51, \mathrm{SD}=.90)$ while assumptions $(\mathrm{M}=3.37, \mathrm{SD}=.79)$ emerged the third. The least rated form of organizational culture was artifacts $(\mathrm{M}=3.30, \mathrm{SD}=.83)$ which was almost moderately practiced even though still high. The overall mean of the organizational culture was high $(\mathrm{M}=3.49, \mathrm{SD}=.63)$. These findings imply that organizational culture in the public universities clearly manifests to a large extent.

The third step in the determination of the effect of organizational culture on organizational performance was establishing the relationship between organizational culture and performance. Pearson product moment correlation was used in coming up with the correlation between the organizational culture variables and performance. First, the four variables of the organizational culture were correlated with organizational performance and the results presented as shown in Table 4.6 that follows.

Table 4.6 Correlation between organizational Culture and Organizational Performance

\begin{tabular}{|c|c|c|c|c|c|c|}
\hline & Variables & 1 & 2 & 3 & 4 & 5 \\
\hline 1 & Organizational Performance & 1 & $.778^{* *}$ & $.765^{* *}$ & $.562^{* *}$ & $.504^{* *}$ \\
\hline 2 & Values & & 1 & $.766^{* *}$ & $.518^{* *}$ & $.465^{* *}$ \\
\hline 3 & Artifacts & & & 1 & $.484^{* *}$ & $.500^{* *}$ \\
\hline 4 & Individual Belief & & & & 1 & $.431^{* *}$ \\
\hline 5 & Assumptions & & & & & 1 \\
\hline
\end{tabular}

The findings in Table 4.6 indicates that there is a strong positive significant correlation between organizational values and organizational performance $(\mathrm{r}=.778, \mathrm{p}<.05)$. It is also clear from the findings that organizational artifacts positively and strongly correlate with organizational performance, $(\mathrm{r}=.765, \mathrm{p}<.05)$ a correlation that is significant. However, organizational individual believes and assumptions had moderate positive 
significant correlations with organizational performance $(r=.562, \mathrm{p}<.05)$ and $(\mathrm{r}=.504, \mathrm{p}<.05)$ respectively.

Further correlation was carried out between the overall mean scores of the four forms of organizational culture and organizational performance. This was intended to establish the overall strength and magnitude of the correlation between organizational culture as a whole and organizational performance. The findings are presented as shown in Table 4.7 that follows.

Table 4.7 Overall Correlations between Organizational Culture and Organizational Performance

\begin{tabular}{|c|c|c|c|}
\hline & & $\begin{array}{c}\text { Organizational } \\
\text { Performance }\end{array}$ & $\begin{array}{l}\text { Organizational } \\
\text { Culture }\end{array}$ \\
\hline \multirow{3}{*}{ Organizational Performance } & Pearson Correlation & 1 & $.804^{* *}$ \\
\hline & Sig. (2-tailed) & & .000 \\
\hline & $\mathrm{N}$ & 203 & 203 \\
\hline \multirow{3}{*}{ Organizational Culture } & Pearson Correlation & $.804^{* *}$ & 1 \\
\hline & Sig. (2-tailed) & .000 & \\
\hline & $\mathrm{N}$ & 203 & 203 \\
\hline
\end{tabular}

**. Correlation is significant at the 0.01 level (2-tailed).

Source: Spss data 2017

The findings in Table 4.7 indicates that there is a strong positive significant correlation between organizational culture and organizational performance $(\mathrm{r}=.804, \mathrm{p}<.05)$. This implies that there is a strong relationship between organizational culture and organizational performance. Therefore organizational performance is associated with organizational culture such that the better the organizational culture, the better the organizational performance. As the last step, the study finally sought the effect of organizational culture on organizational performance of the public universities. The study hypothesis read that "H02: There is no significant relationship between organization culture on organization performance of public universities in Kenya" while the objective of the study was to determine the effect of the organizational culture on organizational performance of public universities. Standard multiple linear regression model was carried out. Organizational performance was regressed against the four forms of organizational culture, which were; assumptions, individual believes, artifacts, and values. The model summary results are presented as shown in Table 4.8 that follows.

Table 4.8, Summary Model Results on the Effect of Organizational Culture on Performance

\begin{tabular}{|c|c|c|c|c|c|c|c|c|c|}
\hline \multirow{2}{*}{$\begin{array}{c}\text { Mod } \\
\text { el }\end{array}$} & \multirow[t]{2}{*}{$\mathbf{R}$} & \multirow{2}{*}{$\begin{array}{c}\mathbf{R} \\
\text { Square }\end{array}$} & \multirow{2}{*}{$\begin{array}{l}\text { Adjusted } \\
\text { R Square }\end{array}$} & \multirow{2}{*}{$\begin{array}{l}\text { Std. Error } \\
\text { of the } \\
\text { Estimate }\end{array}$} & \multicolumn{5}{|c|}{ Change Statistics } \\
\hline & & & & & $\begin{array}{c}\text { R Square } \\
\text { Change }\end{array}$ & $\begin{array}{c}\text { F } \\
\text { Change }\end{array}$ & df1 & df2 & $\begin{array}{c}\text { Sig. F } \\
\text { Change }\end{array}$ \\
\hline 1 & $.837^{\mathrm{a}}$ & .700 & .694 & .33402 & .700 & 115.508 & & 198 & .000 \\
\hline
\end{tabular}

a. Predictors: (Constant), Assumptions, Individual Belief, Artifacts, Values

Source: Spss data 2017 
The findings in Table 4.8 indicates that there was a positive significant multiple correlation between the four forms of organizational culture and organizational performance $(\mathrm{R}=.837)$. It is also clear from the model that organizational culture accounts for $70.0 \%$ variance in organizational performance ( $\mathrm{R}$ square $=.700, \mathrm{p}=.000$ ). An adjusted $\mathrm{R}$ square value further indicates that organizational culture accounts for $69.4 \%$ after shrinkage, or controlling for overestimation or under estimation of the estimate values (Adjusted R square value=.694). These findings were significant, or not by chance $(F(4,198)=115.508)$, but as a results of fitting the model. It can thus be deduced from the findings that organizational culture explains a bigger percentage of the organizational performance in public universities. It was thus necessary to establish the effect of each of the forms of organizational culture on organizational performance. The findings are presented as shown in Table 4.9 that follows.

Table 4.9 Effect of Organizational Culture on Performance (Using Model Coefficients)

\begin{tabular}{|c|c|c|c|c|c|c|}
\hline & \multirow[t]{2}{*}{ Model } & \multicolumn{2}{|c|}{$\begin{array}{l}\text { Unstandardized } \\
\text { Coefficients }\end{array}$} & \multirow{2}{*}{$\begin{array}{c}\text { Standardized } \\
\text { Coefficients } \\
\text { Beta } \\
\end{array}$} & \multirow[t]{2}{*}{$\mathbf{t}$} & \multirow[t]{2}{*}{ Sig. } \\
\hline & & B & Std. Error & & & \\
\hline \multirow{5}{*}{1} & (Constant) & .644 & .151 & & 4.268 & .000 \\
\hline & Values & .375 & .060 & .394 & 6.257 & .000 \\
\hline & Artifacts & .253 & .046 & .347 & 5.519 & .000 \\
\hline & Individual Belief & .103 & .031 & .155 & 3.283 & .001 \\
\hline & Assumptions & .061 & .035 & .080 & 1.719 & .087 \\
\hline
\end{tabular}

a. Dependent Variable: Mean Organizational Performance

Source: Spss data 2017

The findings in Table 4.9 indicate the effects or the contributions of each of the forms of the organizational culture on organizational performance. The model coefficients clearly indicates that organizational values had the highest unique contribution to the organizational performance $(\beta=.394$, $\mathrm{p}=.000$ ). This was the variable with the highest significant effect as compared to the other variables. The second variable that uniquely contributed to the organizational performance was the organizational artifacts $(\beta=.347, \mathrm{p}=.000)$. The third variable with the least significant unique contribution to performance was individual believes $(\beta=.155, \mathrm{p}=.001)$. However, organizational assumption did not have a significant contribution to organizational performance in this model. This could be due to the overlapping effect of the other variables. It can also be said that the compared contribution of the variables could have rendered the organizational cultures to being non significant due to the less role it plays in the universities organizational culture. Before reaching a conclusion, the overall mean scores of organizational performance were also regressed against the overall mean scores of organizational culture using a simple linear regression model. In this case, all 
the forms of organizational culture were summarized into single means scores. The scores for the findings for the summary model results are presented as shown in Table 4.10 that follows.

Table 4.10 Summary Model Results on the Effect of Organizational Culture on Organizational Performance

\begin{tabular}{|c|c|c|c|c|c|c|c|c|c|}
\hline \multirow[t]{2}{*}{ Model } & \multirow[t]{2}{*}{$\mathbf{R}$} & \multirow{2}{*}{$\begin{array}{c}\mathbf{R} \\
\text { Square }\end{array}$} & \multirow{2}{*}{$\begin{array}{c}\text { Adjusted R } \\
\text { Square }\end{array}$} & \multirow{2}{*}{$\begin{array}{l}\text { Std. Error } \\
\text { of the } \\
\text { Estimate }\end{array}$} & \multicolumn{5}{|c|}{ Change Statistics } \\
\hline & & & & & $\begin{array}{l}\text { R Square } \\
\text { Change }\end{array}$ & $\begin{array}{c}\text { F } \\
\text { Change } \\
\end{array}$ & df1 & df2 & $\begin{array}{c}\text { Sig. F } \\
\text { Change }\end{array}$ \\
\hline 1 & $.804^{\mathrm{a}}$ & .646 & .645 & .35989 & .646 & 367.542 & & 201 & .000 \\
\hline
\end{tabular}

a. Predictors: (Constant), Mean Organizational Culture

Source: Spss data 2017

The findings in Table 4.10 indicates that there was a high positive correlation between organizational culture and performance $(\mathrm{R}=.804)$. Organizational culture also accounted for $64.6 \%$ change or variance in organizational performance ( $\mathrm{R}$ square $=.646$ ) and $64.5 \%$ after adjusting for over estimation of the model results (adjusted $\mathrm{R}$ square $=.646$ ). The findings were significantly as a result of fitting the model $(\mathrm{F}(1,201)=367.54, \mathrm{p}=.000$. The findings thus indicates that organizational culture explains a large significant change in organizational performance. Finally, the model sought the effect of organizational culture on organizational performance using the model coefficient results whose results are presented as sown in Table 4.11 that follows.

Table 4.11 Effect of Organizational Culture on Organizational Performance

\begin{tabular}{|c|c|c|c|c|c|c|}
\hline \multicolumn{2}{|r|}{ Model } & \multicolumn{2}{|c|}{ Unstandardized Coefficients } & \multirow{2}{*}{$\begin{array}{c}\text { Standardized } \\
\text { Coefficients } \\
\text { Beta }\end{array}$} & \multirow[t]{2}{*}{$\mathbf{t}$} & \multirow[t]{2}{*}{ Sig. } \\
\hline & & B & Std. Error & & & \\
\hline & (Constant) & .790 & .141 & & 5.585 & .000 \\
\hline 1 & Organizational Culture & .764 & .040 & .804 & 19.171 & .000 \\
\hline
\end{tabular}

a. Dependent Variable: Mean Organizational Performance

Source: Spss data 2017

The findings in Table 4.11 indicates that organizational culture has a unique positive and significant contribution to performance $(\beta=.804, p=.000)$. This implies that organizational culture has a strong effect on organizational performance.

Further insight from the results indicated in Table 4.11 was also deduced. Organizational culture standardized beta values indicate the number of standard deviations that scores in the organizational performance variable would change if there was a one standard deviation unit change in the organizational culture. From these findings, if we could increase organizational culture by one standard deviation (which is 0.63 , from the Descriptive Statistics table), then the organizational performance scores would be likely to increase by 0.804 standard deviation units. 
If we multiplied this value by .63 (the standard deviation of organizational culture scores), we would get $.804 \times \times 63=.5065$. When this value is multiplied by $100 \%$, it implies that putting more effort on organizational culture leads to a 50\% increase in organizational performance. Thus organizational culture could lead to over half the increase in organizational performance.

The findings are in line with ul Mujeeb and Ahmad 2011; Nikpour, 2017 who indicated that organization culture had a positive impact on employee organization commitment and organization performance. Therefore, it is anticipated that there is a strong positive significant correlation between organizational culture and organizational performance. The findings are also in support to Tsai, (2011); Agwu (2014) who similarly find a positive significance relationship between organizational culture and performance basing on values, believes and norms. They therefore concluded that organization culture had an influence on performance.

On the contrary, the findings of this study differs with those of Aluko, (2003) whose study revealed that cultural variables showed a high level of commitment to work, low level of labor turnover and absenteeism, positive beliefs about work, positive work values, attitudes, and norms in all the firms studied. But these positive attributes did not translate directly to high level of organizational performance in these mills because some other variables were at work, which was also in support to Wahjudi.et.al (2016), Shi, Veenstra \& Lee-Chin. (2017) study that revealed, organization culture only explains $20 \%$ of a firm's performance, and some of the variables used to measure culture had a negative effect on performance. From there findings, which were significant, or not by chance, but as a results it can thus be deduced from the findings that organizational culture explains a bigger percentage of the organizational performance in an organization.

\subsection{Discussion}

The findings from results using Pearson Product Moment Correlation, indicates that there was a strong positive significant correlation between organizational culture and organizational performance $(\mathrm{r}=.804, \mathrm{p}<.05)$. Regression analyses revealed that organizational values had the strongest unique contribution to the organizational performance $(\beta=.394, p=.000)$, followed by organizational artifacts $(\beta=.347, p=.000)$ and finally individual believes $(\beta=.155, \mathrm{p}=.001)$. Organizational assumption did not have a significant contribution to organizational performance in this model. The overall form of organizational culture had a unique significant contribution on organizational performance $(\beta=.804, p=.000)$, and accounted for $64.6 \%$ variance in organizational performance. An alternative hypothesis was 
therefore, adopted to indicate that organizational culture had an effect on organizational performance.

\subsection{Conclusion}

Organizational culture is paramount to the organizational performance in public universities in Kenya. This is because as the culture of the universities changes to be positive, there is consequent improvement in organizational performance. Organizational culture thus has a strong positive effect on organizational performance and therefore a strong determinant of organizational performance of the universities. One of the most important aspects that determine the organizational performance is the organizational values, which directly translates the performance to an improvement

\section{References:}

1. Acar, A. Z., \& Acar, P. (2012). The effects of organizational culture and innovativeness on business performance in healthcare industry. Procedia-Social and Behavioral Sciences, 58, 683-692.

2. Agwu, M. O. (2014). Organizational Culture and Employees Performance in the National Agency for Food and Drugs Administration and Control (Nafdac), Nigeria. Global Journal of Management And Business Research, 14(2).

3. Ali, A. S., \& Rahmat, I. (2010). The performance measurement of construction projects managed by ISO-certified contractors in Malaysia. Journal of Retail \& Leisure Property, 9(1), 25-35.

4. Allard, I. N. (2010). Examining the relationship between organizational culture and performance:Moderators of culture gap (Doctoral dissertation, North-central University).

5. Aluko, M.A.O. (2003) 'The impact of culture on organizational performance in selected textile firms in Nigeria', Nordic Journal of African Studies, Vol. 12, No. 2, pp.164-179.

6. Chang'ach, J. K. (2014). Postmodernism as a Social Science Methodology\&58; Comments on Haugerud's Representation of Kenya. Asia Pacific Journal of Multidisciplinary Research, 2(3), 7075.

7. Deal, T. E., \& Peterson, K. D. (2006). Shaping school culture. John Wiley \& Sons.

8. Fakhar, S., Iqbal, I., \& Gulzar, M. (2014). Impact of Organizational Culture on Employees Job Performance: An Empirical Study of Software Houses in Pakistan Journal of Business Studies Quarterly, $5(2)$. 
9. Kothari, C. R. (2004). Research methodology: Methods and techniques. New Age International.

10. Guler, I., Guillén, M. F., \& Macpherson, J. M. (2002). Global competition, institutions, and the diffusion of organizational practices: The international spread of ISO 9000 quality certificates. Administrative science quarterly, 47(2), 207-232.

11. Lapiņa, I., Kairiša, I., \& Aramina, D. (2015). Role of Organizational Culture in the Quality Management of University. Procedia-Social and Behavioral Sciences, 213, 770-774.

12. Mathooko, F. M. (2013). Response strategies adopted by public universities in Kenya to environmental and managerial challenges (Doctoral dissertation, University of Nairobi,).

13. Mohammad Mosadegh Rad, A. (2006). The impact of organizational culture on the successful implementation of total quality management. The TQM Magazine, 18(6), 606-625.

14. Naranjo-Valencia, J. C., Jiménez-Jiménez, D., \& Sanz-Valle, R. (2016). Studying the links between organizational culture, innovation, and performance in Spanish companies. Revista

Latinoamericana de Psicología, 48(1), 30-41.

15. Nikpour, A. (2017). The impact of organizational culture on organizational performance: The mediating role of employee's organizational commitment. International Journal of Oganizational Leadership, 6(1), 65.

16. Tsai, Y. (2011). Relationship between organizational culture, leadership behavior and job satisfaction. BMC health services research, 11(1), 98.

17. ul Mujeeb, E., \& Ahmad, M. S. (2011). Impact of organizational culture on performance management practices in Pakistan. International Management Review, 7(2), 52.

18. Wahjudi, D., Singgih, M. L., Suwignjo, P., \& Baihaqi, I. (2016). The relationship between organisational culture and firm performance: an empirical study on Indonesian manufacturing firms. International Journal of Productivity and Quality Management, 18(1), 1-18.

19. Zhu, A. Y., von Zedtwitz, M., Assimakopoulos, D., \& Fernandes, K. (2016). The impact of organizational culture on Concurrent Engineering, Design-for-Safety, and product safety performance. International Journal of Production Economics, 176, 69-81. 